\title{
Introduction to the special section on multiple myeloma
}

\author{
Connie Y. Chang ${ }^{1} \cdot$ William E. Palmer ${ }^{1}$
}

Published online: 6 October 2021

(c) ISS 2021

The landscape of multiple myeloma has changed rapidly during the past ten years. Treatments have improved as we gain a deeper understanding of the disease. The International Skeletal Society is well positioned to harness interdisciplinary expertise on this topic. Our authors for this special issue include pathologists, oncologists, and radiologists. Dr. Fitzpatrick, Dr. Nardi, and Dr. Sohani review the most recent multiple myeloma cytogenetics in "Plasma cell myeloma: role of histopathology, immunophenotyping, and genetic testing" [1]. Cytogenetics is now a critical driving force behind treatment decision-making, and is the primary reason for bone marrow sampling, which is reviewed in "Bone marrow aspiration and biopsy: techniques and practice implications" by Dr. Tomasian and Dr Jennings [2]. With improved therapy and patient survival, demand has increased for early diagnosis, bone marrow characterization, and the differentiation of treatment-related change from recurrent or residual disease. Dr. Lecouvet and colleagues address whole-body MRI and PET/CT in "Imaging of treatment response and minimal residual disease in multiple myeloma: state of the art WB-MRI and PET/CT" [3]. Dr. Vicentini and Dr. Bredella delve deeper into the "Role of FDG PET in the staging of multiple myeloma," especially its role across the spectrum of disease, including smoldering multiple myeloma and plasmacytoma [4].

In "Myeloma response assessment and diagnosis system (MY-RADS): strategies for practice implementation,” Dr. Mulligan highlights an example dictation template, which may be helpful for radiologists who are new to whole-body MRI [5]. Dr. Vande Berg and colleagues address the marrow involvement patterns, which may also be helpful to radiologists interpreting MRI scans in patients with myeloma and other infiltrative disorders of bone marrow [6]. Dr. Van Den Berghe and colleagues discuss the added value of

Connie Y. Chang

cychang@mgh.harvard.edu

1 Massachusetts General Hospital and Harvard Medical School, 55 Fruit Street Yawkey 6E, Boston, MA 02114, USA diffusion and dynamic contrast imaging to routine MRI [7]. Dr. Rosenthal has not only chosen the most creative title ("Floccinaucinihilipilification: is there a continuing role for the radiographic skeletal survey?"), he has also presented a thought-provoking analysis of the evolving imaging methods for multiple myeloma [8]. Most of these changes have been both oncologist-driven and radiologist-driven, which is why we felt that the article by Dr. Shapiro and Dr. O'Donnell titled "Oncologist perspective: role of imaging in myeloma" was so important to include in this special section [9]. Finally, Dr. Stanborough and Dr. Garner describe atypical musculoskeletal findings and mimics of myeloma in "Multiple myeloma: a review of atypical imaging features and other distinct plasma cell disorders that demonstrate similar imaging features" [10].

We are excited to present this comprehensive update on multiple myeloma imaging and related topics, and we hope that our readers will find it helpful in their clinical practices. We are indebted to all the authors for their extraordinary contributions of time and expertise. The Editors of Skeletal Radiology and our inaugural ISS Founders' Fellow in Musculoskeletal Publishing are thrilled to publish this special focused section-the first of its kind for our Journal.

\section{Declarations}

Research involving human and animal participants This article does not contain any studies with human participants performed by the authors.

Conflict of interest The authors declare that they have no conflict of interest.

\section{References}

1. Fitzpatrick MJ, Nardi V, Sohani AR. Plasma cell myeloma: role of histopathology, immunophenotyping, and genetic testing. Skelet Radiol. 2021. https://doi.org/10.1007/s00256-021-03754-3. 
2. Tomasian A, Jennings JW. Bone marrow aspiration and biopsy: techniques and practice implications. Skelet Radiol. 2021. https:// doi.org/10.1007/s00256-021-03882-w.

3. Lecouvet FE, Vekemans MC, Van Den Berghe T, et al. Imaging of treatment response and minimal residual disease in multiple myeloma: state of the art WB-MRI and PET/CT. Skelet Radiol. 2021. https://doi.org/10.1007/s00256-021-03841-5.

4. Vicentini JRT, Bredella MA. Role of FDG PET in the staging of multiple myeloma. Skelet Radiol. 2021. https://doi.org/10.1007/ s00256-021-03771-2.

5. Mulligan ME. Myeloma response assessment and diagnosis system (MY-RADS): strategies for practice implementation. Skelet Radiol. 2021. https://doi.org/10.1007/s00256-021-03755-2.

6. Vande Berg BC, Kirchgesner T, Acid S, Malghem J, Vekemans MC, Lecouvet FE. Diffuse vertebral marrow changes at MRI: multiple myeloma or normal? Skelet Radiol. 2021. https://doi.org/10. 1007/s00256-021-03886-6.

7. Van Den Berghe T, Verstraete KL, Lecouvet FE, et al. Review of diffusion-weighted imaging and dynamic contrast-enhanced MRI for multiple myeloma and its precursors (monoclonal gammopathy of undetermined significance and smouldering myeloma). Skelet Radiol. 2021. https://doi.org/10.1007/s00256-021-03903-8.

8. Rosenthal DI. Floccinaucinihilipilification: is there a continuing role for the radiographic skeletal survey? Skelet Radiol. 2021. https://doi.org/10.1007/s00256-021-03780-1.

9. Shapiro YN, O'Donnell EK. Oncologist perspective: role of imaging in myeloma. Skelet Radiol. 2021. https://doi.org/10.1007/ s00256-021-03856-y.

10. Stanborough RO, Garner HW. Multiple myeloma: a review of atypical imaging features and other distinct plasma cell disorders that demonstrate similar imaging features. Skelet Radiol. 2021. https://doi.org/10.1007/s00256-021-03792-x.

Publisher's note Springer Nature remains neutral with regard to jurisdictional claims in published maps and institutional affiliations. 